RESEARCH ARTICLE

\title{
Another Way for Deepening Democracy Without Shortcuts
}

\author{
Tetsuki Tamura
}

This article examines Democracy without Shortcuts by Cristina Lafont, focusing on its key concept of self-government. Lafont's argument and criticism of existing democratic theories in terms of the self-government perspective are very persuasive and insightful. However, this article argues that this perspective can be extended by referring to the recent development of the deliberative systems approach and considering its theoretical implications. The participatory conception of deliberative democracy argued in this book can be reconfigured by multiplying the sites of self-government.

Keywords: deliberative democracy; deliberative systems; self-government; family; multiple selfgovernments; private sphere

As dissatisfaction with democracy reaches a 'record-high' (Foa, Klassen, Slade, Rand and Collins 2020), democratic theorists are challenged to reconceptualize the ideal of democracy suitable for our times. Deliberative democracy is one of the most appealing options on the table today. All over the world, we have witnessed the explosion of experiments in democratic deliberation which aim to connect the voices of ordinary citizens to policymaking in various levels of governance (see Chwalisz 2019). These procedures, often called deliberative minipublics, have been welcomed by many scholars, practitioners, and policymakers for their track record in bridging polarized discourses, generating mutually acceptable decisions, and promoting political efficacy among citizens who have lost trust in democracy (Fishkin 2009; Fung 2007; Gastil and Levin eds. 2005; Grönlund, Bächtiger, and Setälä 2014; Smith 2009). The growing interest in minipublics is sometimes referred to as the institutional turn of the deliberative democracy research (Chambers 2003).

Within the scholarship of deliberative democracy, however, there have been strong critiques about the democratic quality of minipublics. This critique is most strongly articulated by Cristina Lafont (2019) in her book Democracy without Shortcuts, where she raises concerns about how minipublics could undermine the democratic ideal of self-government by promoting blind deference to the decision of minipublics (Ibid: 111). She then argues that only the 'participatory' conception of deliberative democracy can defend democracy in hard times. By this, she means a type of deliberation for 'justifying the coercive

Nagoya University, JP

tamura@law.nagoya-u.ac.jp power that citizens exercise over one another by trying to convince each other of reasonableness of the policies to which they are subject' (Lafont 2019: 168).

While recognizing the significance of Lafont's critique of minipublics, I propose another way for deepening democracy without shortcuts. Her criticism of democratic theories from the perspective of selfgovernment is persuasive but this can be enriched by engaging recent developments in the deliberative systems approach to deliberative theory. I argue that the participatory conception of deliberative democracy can be reconceptualized by problematizing the sites where deliberation takes place and extending the democratic ideal of self-government to private spheres.

I develop this argument in three sections. First, I summarise and confirm the points of Lafont's argument. Second, I argue why pluralizing the concept of selfgovernment is important. Finally, I draw a sketch of the multiple self-governments, where the deliberative system approach is applied and revised and the family is examined as a case.

\section{Self-government as the Normative Criterion and Criticism of Democratic Theories}

Democratic theorists, including deliberative democrats, consider political equality as one of the normative bases of deliberative democracy (see Swift 2006: 209213; Dahl 1998; Beauvais 2018). Realizing the ideal of political equality is manifest in the design of minipublics through random selection and the equal consideration of participants' preferences (Fishkin 2009: 43, 54-55). Lafont contends that political equality is insufficient to defend the significance of democracy because it 'does not rule out political alienation' (Lafont 2019: 19). Aside from political equality, the substance of laws and policies that citizens 
are bounded to obey must be considered (Lafont 2019: 19-22). Therefore, she identifies self-government as the fundamental concept of democracy. By self-government, Lafont refers to the democratic ideal where all citizens can equally own and identify with the institutions, laws and politics to which they are subject' (Ibid: 3). To realise self-government, citizens must have 'some form of democratic control over political decision-making by the citizenry' (Ibid: 7). Democratic control is compromised when citizens are expected to 'blindly defer' to decisions made by others (Ibid: 8 ). At risk with blind deference is the 'misalignment' between what citizens believe and the content of the laws to which they are subject. Blind deference, Lafont argues, is a form of a 'shortcut' which bypasses 'public deliberation about political decisions' (Ibid: 3). This only serves to worsen than improve on democratic deficits contemporary societies face.

Various theories of democracy fail to uphold the political ideal of self-government. Deep pluralist theories, which include not only the 'purely proceduralist' approach emphasizing majority rule but also agonistic pluralists (Lafont 2019: Chapter 2), are criticized for shortcutting the democratic process. For deep pluralists, due to the impossibility of overcoming serious disagreements among citizens, majoritarian procedures are the 'only fair way' to settle them (Ibid: 54). However, relying on majoritarian procedures means the 'procedural shortcut' (Ibid: 35) for solving disagreements because it removes political decisions from participatory moments, from debates in the public sphere' (Ibid: 3). Lafont also criticises epistemic democracy for its shortcut of democratic process based on citizens' political ignorance (Ibid: Chapter 3). Focusing exclusively on the substantive quality of outcomes will bring technocratic understanding of politics and result in an expertocratic shortcut.

Deliberative democracy itself, Lafont argues, is not immune from democratic shortcuts. She criticises the 'lottocratic' conceptions of deliberative democracy or those that focus exclusively on minipublics (Ibid: Chapter 4). Although there are two reasons for justifying the decisional status of minipublics, both result in blind deference. The epistemic justification brings blind deference to experts and the democratic justification leads to blind deference to the majority. In order to avoid these shortcuts, Lafont emphasizes the pursuit of a 'macro-deliberative strategy' (Ibid: 134-136). For her, the 'micro-deliberative strategy' of using minipublics is optional or dispensable for the realization of deliberative democracy' and must be rejected (Ibid: 135-136). Instead of using minipublics as shortcuts, Lafont proposes not to empower minipublics but to explore democratic uses of them for empowering the citizenry so that they 'can reach a considered opinion in the political decisions to which they are subject' (Ibid: 146). They include contestatory, vigilant, and anticipatory uses of minipublics. The contestatory uses of minipublics mean, given the actual divide of public opinion between consolidated majority and a dissenting minority, utilizing the 'independent evidence provided by minipublics' to 'help minorities challenge consolidated majorities' and then to scrutinize public opinions. The vigilant uses of minipublics mean that minipublics function to signal the citizenry that the 'political system is not responsive to their needs to have access to quality information' (Ibid: 152). Finally, the anticipatory uses of minipublics mean that minipublics take the role of demonstrating what citizens would think when enough information and knowledge are provided to them (Ibid: 146-159).

Lafont's arguments are persuasive especially in identifying how various models of democracy endorse shortcuts that compromise the ideal of self-government. There is, however, a missed opportunity in Lafont's work, which is to engage in developments in deliberative democracy beyond the study of minipublics. In the next section, I propose a pluralistic concept of self-government by contextualizing this concept to various sites of deliberation.

\section{Pluralizing the Concept of Self-government}

One taken-for-granted assumption in Lafont's work is about the different sites where democracy unfolds. Throughout the book, Lafont assumes that democracy takes place in institutions of the state and government, thereby limiting her conceptualization of what selfgovernment means in democratic life. Such focus of analysis has blind spots. For decades, democratic theorists and empirical social scientists have drawn their attention to extra-institutional sites of democratic practice where decisions and possible manifestations of blind deference are manifest (Ercan, Hendriks, and Boswell 2018; Felicetti 2018; Mendonça and Ercan 2015; Nishiyama 2019; Rowe 2018).

In my critique, I particularly focus on the many sites of deliberative democracy. Scholars of deliberative democracy have long acknowledged that 'deliberation occurs in multiple and partly overlapping sites' (Ercan and Dryzek 2015: 242). Debates over the 'all affected principle' and the 'all subjected principle' emphasize the non-obviousness of sites of democracy (Goodin 2007; Fraser 2008: Chapter 4). While Lafont certainly examines the shortcuts in self-government in various democratic conceptions, the question of where democracy is located is hardly discussed.

To be fair, Lafont is aware of this problem. She states that 'a participatory concept of participatory democracy' proposed in her book 'necessarily aims at achieving higher levels of citizen participation in direct political action' and that 'it may also welcome proposals for extending democracy to the workplace, the family, and so on' (Lafont 2019: 29). This recognition, however, only comes in a footnote.

However, as with the question of political activism, the proper extension of democracy beyond the political system is an open question that participatory conceptions of deliberative democracy may answer in different ways. Addressing this complex question is beyond the scope of this book. (Ibid: 29, note 22 , emphasis mine) 
There are obviously good reasons why a book needs to limit the scope of the study. In this case, Lafont decides to set the parameters of her discussion to democracy within the political system. This, I argue, is a critical flaw. For a book that makes a case for the participatory conception of democracy, it is essential to recognize that participation takes place beyond the political system. Limiting the discussion of shortcuts and blind deference within the political system, in other words, is too narrow to develop a participatory conception of deliberative democracy.

Let me elaborate on this argument. I support Lafont's view that blind deference to the decisions of others is a violation of self-government and therefore a threat to democratic control. However, the problem to be considered here is the scope of 'decision of others.' By stating that ' $\mathrm{t}] \mathrm{h}$ he proper extension of democracy beyond the political system' is 'beyond the scope of this book,' she implicitly assumes that 'decision of others' is made only at the 'political system' level. However, we can re-examine the decision of others as something made in multiple layers of power dynamics surrounding us; for example, decision by community members in one's area of residence, decision by colleagues in the workplace, decision by classmates in schools, decision by football teammates in community events, and even decision by family members. All of these are 'decisions of others' on issues related to different sites where one belongs. Citizens are then exposed to a variety of 'decision of others' in various settings and may therefore 'blindly defer to the decisions of others' in diverse sites. Deference, therefore, is pluralized. ${ }^{1}$ When Lafont uses the term of political system, the state or government is probably assumed to be the 'system.' However, there can be more than one political system, and therefore the possibility of our 'blind deference to the decisions of others' exists in multiple dimensions.

These considerations lead us to radicalize the concept of self-government which is the key normative criterion in Lafont's book. If the ideal of self-government 'to ensure that all citizens can equally own and identify with institutions, laws, and policies to which they are subject' is fundamental to democracy, its scope should not be limited to 'institutions, laws, and policies' in the state or government dimension (Lafont 2019: 3). Almost all of them are not only at the state or government but also at any other sites and locations related to us should be subject to self-government. The public sphere, for example, is not only a site for better opinion formation whose transmission to decision-making at the state or government is expected, but also should be examined as a site of decision-making on issues appearing among people there. This investigation finally leads to selfgovernment in the private sphere, which includes family and friendship. The private sphere is not only a site for opinion formation and political socialization but also a site for decision-making. Decisions made in the home are not limited in the intimate sphere but expand to other spheres of life including economy, society, and policy. Thus, the radicalization of self-government means understanding the sites and objects of self-government as more pluralized and multi-layered.

\section{Multiple Self-governments and Nested Deliberative Systems}

It should be emphasized that such arguments in the previous section are not necessarily far-fetched in research into deliberative democracy, especially with the systemic turn' in deliberative democracy (Dryzek 2010; Elstub et al. 2018; Parkinson 2006; Parkinson and Mansbridge 2012). ${ }^{2}$ Two key points are significant here. The first is that the systemic approach tells us that focusing on individual institutions and/or practices is not sufficient for deliberative democracy research. What we have to look at and examine is the connection between various institutions and practices including non-deliberative ones as a system. This is the reason why a study focusing exclusively on a minipublic is criticized by the deliberative systems approach. Studying minipublics is still important but its focus should be on the connection of such citizen fora with other institutions, spheres, and practices. ${ }^{3}$

The second point of the systemic approach, particularly important for this article, is its theoretical concern in relativizing the state-government centric conception of deliberative democracy. A system is not necessarily conceptualized only at the state or government level. The components of a deliberative system, such as public space, empowered space, transmission, and accountability, are not necessarily what are familiar to us at the state or governmental level (Dryzek 2010). Indeed, a transnational deliberative system is an example of this system (Stevenson and Dryzek 2014). ${ }^{4}$ This concept can be applied not only to sites beyond the state but also to sites below the state. This, I argue, is an important intervention in the development of deliberative systems research. The 'systemic turn' has brought substantive developments in deliberative democracy research and has broadened the scope of deliberation beyond minipublics. However, its tendency to focus on the large or mass scale might lead to lose sight of the opportunity to understand various small sites other than institutionalized minipublics as sites for deliberative democracy to take a participatory character. Rethinking the previous focus on small-scale institutions does not necessarily mean to turn to the large scale; attention to the small-scale, not formally institutionalized spaces is possible. We can apply the concept of deliberation system to the private spheres such as family, friendship and intimate relationships as well as to the national and transnational levels (Tamura 2014). We know that Jane Mansbridge's proposition of the concept of deliberative systems focused on 'everyday talk' in the private sphere (Mansbridge 1999). ${ }^{5}$ Even in the case of family and friends, in order to resolve disagreements and conflicts, members will have to make decisions in a way that is reasonably acceptable to each other even if it includes moments of conflict. If the process leading to this decision is seen as deliberative, it can be examined in terms of the systemic perspective. The private sphere can be conceptualized as a part of the nested deliberative systems where it is not only a component of the macrodeliberative system but also a system by itself where opinion formation and decision making would be done in a manner similar to those at the macro-level system even 
without formal political institutions (Tamura 2014; 2017: Chapter 8). Conceptualizing the family as a deliberative system at a micro-level means that we can examine even institutions and spaces outside a family in the usual sense as components of the family which is a deliberative system (Tamura 2019). Therefore, the boundary of the family as a deliberative system does not necessarily coincide with that of the family in the usual sense. ${ }^{6}$

How can we examine the family as a deliberative system by using concepts of the deliberative systems approach? I sketch it out here relying on the conceptualization of components of a deliberative system by Dryzek and colleagues (Dryzek et al. 2019: Chapter 6; Stevenson and Dryzek 2014; Dryzek 2010). Empowered space is necessary because there are conflicts and confrontations even in family, and family members have to resolve them through making decisions. Ideally, they are expected to engage with their issues and make decisions through deliberation. An important point is that the boundary of the public space in the system does not necessarily coincide with that of a family in the usual sense. The public space as a component of the family as a deliberative system can extend beyond the boundary of a family in the usual sense: the 'subaltern counter-public' suggested by Nancy Fraser is brought to mind (Fraser 1997). Due to the strong norm of gender division of labor, women may not be able to understand their situation appropriately and talk critically. The role of subaltern counter-public outside the family in the usual sense is important; it will be able to offer opportunities for women to meet new and possibly oppositional ideas and discourses on family matters and then can encourage them so that they can deliberate with family members. Furthermore, even the parliament or assembly, which is usually supposed as the empowered space for a macrodeliberative system, can be examined as a public space of the family as a deliberative system because parliamentary debates and decisions can be sources of new knowledge and perspectives for family members engaging with deliberative decision making at the empowered space in the family. The relationship between government and family is reversed here. In case of a deliberative system in commonly supposed sense family is a part of public space and parliament is empowered space on the one hand, parliament is a part of public space and empowered space is found in the deliberative system as a family on the other hand. How does transmission occur in a deliberative system as the family? Women empowered in public spaces are understood as one of the actors of transmission connecting the public space outside the family in the usual sense and empowered space inside it. The accountability of empowered space to the public space, including the subaltern counter-public, should be secured. However, it might be more difficult to figure out both transmission and accountability in the family as a deliberative system than other (more macrolevel) deliberative systems because it might not rely on any representative institutions; it might be a more direct democratic system. Finally, reflexivity means that the reconstruction of the family as a system should be deliberative. The structure of the family as a deliberative system is not static. Its comprehensive transformation, including divorce, is feasible. Reflexivity is important when we seek to avoid static, structural-functionalist examination in the deliberative systems approach (Curato et al. 2018; Mansbridge et al. 2012; Tamura 2014). The form and boundary of the family as a deliberative system can be seen as performative (Bächtiger and Parkinson 2018), ${ }^{7}$ and it is contingent which practice, rule, or (informal) institution can perform which function of the deliberative system. These are tentative, still insufficient, but show that the systemic approach can deal with multiple self-governments at multiple sites.

\section{Components and their descriptions of the family as a deliberative system.}

\section{Components Their Descriptions in the Family as a Deliberative System \\ Empowered Decision making by the family members \\ space \\ Public space Venues and forums located outside the family in the usual sense, from subaltern counter-publics' to even the state, can be included. \\ Transmission Transmission can be performed by women and empowered at the public space can take accountability it. Accountability must be ensured. But family as a deliberative system might be direct-democratic. \\ Reflexivity Reconstruction and even deconstruction (e.g. divorce) of the family should be deliberative.}

With these two points in mind, how can we evaluate Lafont's original arguments on democracy without shortcuts? First, it is true that her arguments contain a systemic perspective to some extent. She considers the possible forms of connection between actual policymaking, actual public opinion, and considered public opinion (Lafont 2019: Chapter 5). The question is how we can envisage the alternative uses of minipublics that could help improve the quality of public deliberation such that the citizenry can reach a considered opinion on the political decisions to which they are subject' (Ibid: 146). As mentioned earlier, she proposes three types of alternative uses of minipublics and examines them; contestatory, vigilant, and anticipatory. This kind of consideration is systemic. The role and significance of minipublics should be considered in terms of their connection with other components in a society, actual policymaking in the empowered space, actual public opinion in the public space, and transmission between them.

Second, the extent of her systemic analysis is, however, still insufficient. The systemic connection between different components in her case is supposed only between state or government and society. Her concern is a political system in the usual sense. Looking for other 'political systems' in various sites and examining them in terms of the deliberative systemic perspective are crucial 
for multiplying the democratic ideal of self-government proposed by Lafont. This reconceptualization will contribute to the complete decoupling of the deliberative system approach from methodological statism, where the research of democracy is conducted explicitly or implicitly on the premise of the state or something like the state. ${ }^{8}$ While some deliberative democrats attempt to conceptualize a system not as a space but as a network or connection (see Ercan et al. 2018), I think it is still uncertain if such attempts will be able to completely overcome methodological statism. For that purpose, returning our focus to sites which are separated from the state and conceptualizing them as political (and deliberative) systems by themselves are needed.

\section{Conclusion}

This article reviewed Lafont's key normative concept of self-government and showed its usefulness in assessing existing democratic theories. I pointed out the narrowness of her conception of self-government, particularly focusing on the sites-problem of democratic theory. The location of the site of democracy is not self-evident. Therefore, with reference to the deliberative systems approach, I proposed a conception of deliberative democracy based on a pluralized understanding of both self-government and sites of democracy. Another way for defending and deepening the democratic ideal of self-government is possible.

\section{Notes}

${ }^{1}$ In the circumstance of pluralized deference to the decisions of others, the risk of blind deference might increase because some sites of deference will not be equipped with democratic mechanism as we know it such as parliament and political parties. However, it is not so serious a problem as democracy is not necessarily electoral-representative democracy, or liberal democracy in this sense. The idea of deliberative democracy becomes important as it does not necessarily presuppose electoral-representative institutions as we know them; it is not necessarily liberal democratic (Dryzek 2000; 2010; Landemore 2017; Tamura 2017). Democratic legitimacy and accountability can be secured through deliberation. Deliberative democracy might flourish in different cultural contexts where electoral-representative institutions are not necessarily premised (Sass 2018; Wedeen 2008). About different consideration based on the idea of nonelectoral representation with authorization and accountability, see Montanaro (2012).

2 Using the word 'Approach' might be insufficient. Nicole Curato and her co-authors viewed the deliberative system also as an 'emancipatory political project' (Curato et al. 2019: 119ff.).

3 See, for example, Curato and Böker (2016) for the distinction of the 'internal' and 'external' qualities of minipublics based on a comparative analysis of four cases of Canada, Australia, France, and Italy. See also a reflection on a possible connection between minipublics and protest movements from a Japanese case in Tang et al. (2018).
${ }^{4}$ See also Ercan et al. (2019) on another interesting reflection on 'communicative plenty' beyond national boundaries from the systemic perspective.

${ }^{5}$ However, even Mansbridge's conceptualization of 'everyday talk' and 'societal decisions' in her later work (Mansbridge et al. 2012: 8-9) is still insufficient. See Tamura (2014; 2017: Chapter 8).

${ }^{6}$ William Smith (2018) reminds us of the significance of the boundary problem for the deliberative systems approach.

7 The study by Bächtiger and Parkinson (2018) is very useful when we take the functionalist problem seriously, although my usage of the concept of contingency might be different from theirs.

8 See for example Bartelson (2001) and Little and Macdonald (2013) to understand how persistent the tendency of methodological statism is even among scholars whose primary concern is to overcome the state/government centric conception of politics and democracy.

\section{Acknowledgements}

I appreciate helpful and constructive comments from two anonymous reviewers and appropriate assistance by editors.

\section{Competing Interests}

The author has no competing interests to declare.

\section{References}

Bächtiger, A., \& Parkinson, J. (2018). Mapping and measuring deliberation: Towards a new deliberative quality. Oxford: Oxford University Press. DOI: https://doi.org/10.1093/oso/9780199672196.001. 0001

Bartelson, J. (2001). The critique of the state. Cambridge: Cambridge University Press. DOI: https://doi. org/10.1017/CBO9780511490170

Beauvais, E. (2018). Deliberation and equality. In A. Bächtiger, J. S. Dryzek, J. Mansbridge, \& M. E. Warren (Eds.), The Oxford handbook of deliberative democracy (pp. 144-155). Oxford: Oxford University Press. DOI: https://doi.org/10.1093/ oxfordhb/9780198747369.013.32

Chambers, S. (2003). Deliberative democratic theory. Annual Review of Political Science, 6(1), 307-326. DOI: https://doi.org/10.1146/annurev.polisci.6.121901. 085538

Chwalisz, C. (2019). A new wave of deliberative democracy. Carnegie Europe. 26 November. Retrieved from: https://carnegieeurope.eu/2019/11/26/newwave-of-deliberative-democracy-pub-80422

Curato, N., \& Böker, M. (2016). Linking minipublics to the deliberative system: A research agenda. Policy Sciences, 49(2), 173-190. DOI: https://doi.org/10.1007/ s11077-015-9238-5

Curato, N., Hammond, M., \& Min, J. B. (2019). Power in deliberative democracy: Norms, forums, systems. New York: Palgrave Macmillan. DOI: https://doi. org/10.1007/978-3-319-95534-6 
Dahl, R. A. (1998). On democracy. New Haven, CT: Yale University Press.

Dryzek, J. S. (2000). Deliberative democracy and beyond: Liberals, critics, contestations. Oxford: Oxford University Press.

Dryzek, J. S. (2010). Foundations and frontiers of deliberative governance. Oxford: Oxford University Press. DOI: https://doi.org/10.1093/acprof:oso/ 9780199562947.001.0001

Dryzek, J. S., et al. (2019). Deliberative global governance. Cambridge: Cambridge University Press. DOI: https:// doi.org/10.1017/9781108762922

Elstub, S., Ercan, S. A., \& Mendonça, R. F. (Eds.) (2018). Deliberative systems in theory and practice. Abingdon: Routledge. DOI: https://doi. org/10.4324/9781351182645

Ercan, S. A., \& Dryzek, J. S. (2015). The reach of deliberative democracy. Policy Studies, 36(3), 241-248. DOI: https://doi.org/10.1080/01442872.2015.1065969

Ercan, S. A., Hendriks, C., \& Boswell, J. (2018). Reforming democracy in disconnected times: A deliberative systems approach. Paper presented at ECPR Joint Sessions Workshop WS05: Can participatory reforms save representative democracy? 10-14 April 2018, Nicosia, Cyprus.

Ercan, S. A., Hendriks, C., \& Dryzek, J. S. (2019). Public deliberation in an era of communicative plenty. Policy \& Politics, 47(1), 19-36. DOI: https://doi.org/10.1332 /030557318X15200933925405

Felicetti, A. (2018). A deliberative case for democracy in firms. Journal of Business Ethics, 150(3), 803-814. DOI: https://doi.org/10.1007/s10551-016-3212-9

Fishkin, J. (2009). When the people speak: Deliberative democracy and public consultation. New York: Oxford University Press.

Foa, R. S., Klassen, A., Slade, M., Rand, A., \& R. Collins. (2020). The Global Satisfaction with Democracy Report 2020. Cambridge: Centre for the Future of Democracy. Retrieved from: https://www.cam.ac.uk/system/files/ report2020_003.pdf

Fraser, N. (1997). Justice interruptus: Critical reflections on the 'postsocialist' condition. London: Routledge.

Fraser, N. (2008). Scales of justice: Reimagining political space in a globalizing world. Cambridge: Polity Press.

Fung,A. (2007). Minipublics: Deliberative designs and their consequences. In S. W. Rosenberg (Ed.), Can the people govern? Deliberation, participation and democracy (pp. 159-183). New York: Palgrave Macmillan. DOI: https:// doi.org/10.1057/9780230591080_8

Gastil, J., \& Levine, P. (Eds.) (2005). The deliberative democracy handbook: Strategies for effective civic engagement in the twenty-first century. San Francisco, CA: Jossey-Bass.

Goodin, R. E. (2007). Enfranchising all affected interests, and its alternatives. Philosophy \& Public Affairs, 35(1), 40-68. DOI: https://doi.org/10.1111/j.10884963.2007.00098.x

Grönlund, K., Bächtiger, A., \& Setälä, M. (Eds.) (2014). Deliberative minipublics: Involving citizens in the democratic process. Colchester: ECPR Press.
Lafont, C. (2019). Democracy without shortcuts: A participatory conception of deliberative democracy. Oxford: Oxford University Press. DOI: https://doi. org/10.1093/oso/9780198848189.001.0001

Landemore, H. (2017). Deliberative democracy as open, not (just) representative democracy. Dadalus, 146(3), 51-63. DOI: https://doi.org/10.1162/ DAED_a_00446

Little, A., \& Macdonald, K. (2013). Pathways to global democracy? Escaping the statist imaginary. Review of International Studies, 39(4), 789-813. DOI: https:// doi.org/10.1017/S0260210512000551

Mansbridge, J. (1999). Everyday talk in the deliberative system. In S. Macedo (Ed.) Deliberative politics: Essays on democracy and disagreement. New York: Oxford University Press.

Mansbridge, J., et al. (2012). A systemic approach to deliberative democracy. In J. Parkinson \& J. Mansbridge (Eds.). Deliberative systems: Deliberative democracy at the large scale (pp. 1-26). Cambridge: Cambridge University Press. DOI: https://doi.org/10.1017/ CBO9781139178914.002

Mendonça, R. F., \& Ercan, S. A. (2015). Deliberation and protest: Strange bedfellows? Revealing the deliberative potential of 2013 protests in Turkey and Brazil. Policy Studies, 36(3), 267-282. DOI: https://doi.org/10.1080 /01442872.2015.1065970

Montanaro, L. (2012). The democratic legitimacy of self-appointed representatives. The Journal of Politics, 74(4), 1094-1107. DOI: https://doi.org/10.1017/ S0022381612000515

Nishiyama, K. (2019). Enabling children's deliberation in deliberative systems: Schools as a mediating space. Journal of Youth Studies, 22(4), 473-488. DOI: https:// doi.org/10.1080/13676261.2018.1514104

Parkinson, J. (2006). Deliberating in the real world: Problems of legitimacy in deliberative democracy. Oxford: Oxford University Press. DOI: https://doi. org/10.1093/019929111X.001.0001

Parkinson, J., \& Mansbridge, J. (Eds.) (2012). Deliberative systems: Deliberative democracy at the large scale. Cambridge: Cambridge University Press. DOI: https:// doi.org/10.1017/CBO9781139178914

Rowe, P. (2018). The everyday politics of parenting: A case study of mamabake. Journal of Information Technology and Politics, 15(1), 34-49. DOI: https://doi.org/10.108 $0 / 19331681.2017 .1354244$

Sass, J. (2018). Deliberative ideals across diverse cultures. In A. Bächtiger, J. S. Dryzek, J. Mansbridge, \& M. E. Warren (Eds.), The Oxford handbook of deliberative democracy (pp. 86-99). Oxford: Oxford University Press. DOI: https://doi.org/10.1093/ oxfordhb/9780198747369.013.2

Smith, G. (2009). Democratic innovations: Designing institutions for citizen participation. Cambridge: Cambridge University Press. DOI: https://doi. org/10.1017/CBO9780511609848

Smith, W. (2018). The boundaries of a deliberative system: The case of disruptive project. In S. Elstub, S. A. Ercan \& R. F. Mendonça (Eds.). Deliberative 
systems in theory and practice (pp. 14-32). Abingdon: Routledge.

Stevenson, H., \& Dryzek, J. S. (2014). Democratizing global climate governance. Cambridge: Cambridge University Press. DOI: https://doi.org/10.1017/ CB09781139208628

Swift, A. (2006). Political philosophy: A beginners' guide for students and politicians. Second Edition. Cambridge: Polity.

Tamura, T. (2014). Rethinking grassroots participations in nested deliberative systems. Japanese Political Science Review, 2(2), 63-87. DOI: https://doi. org/10.15545/2.63

Tamura, T. (2017). Jyukugi Minshushugi no Konnan: Sono Norikoekata no Seijirironnteki Kôsatsu [Deliberative difficulties and beyond]. Kyoto: Nakanishiya Shuppan.
Tamura, T. (2019). Jyukugi Sisutemu toshiteno Kazoku [Family as a deliberative system]. In T. Tamura (Ed.) Nichijô Seikatsu to Seiji: Kokka Chusinteki Seijizô no Saikentô [Politics and everyday life: Rethinking methodological statism in political science] (pp. 14-32). Tokyo: Iwanami Shoten.

Tang, B., Tamura, T., \& He, B. (2018). Deliberative democracy in East Asia: Japan and China. In A. Bächtiger, J. S. Dryzek, J. Mansbridge, \& M. E. Warren (Eds.), The Oxfordhandbook of deliberative democracy (pp.791804) Oxford: Oxford University Press. DOI: https://doi. org/10.1093/oxfordhb/9780198747369.013.42

Wedeen, L. (2008). Peripheral visions: Publics, power, and performance in Yemen. Chicago, IL: The University of Chicago Press. DOI: https://doi.org/10.7208/ chicago/9780226877921.001.0001

\footnotetext{
How to cite this article: Tamura, T. (2020). Another Way for Deepening Democracy Without Shortcuts. Journal of Deliberative Democracy, 16(2), pp.89-95. DOl: https://doi.org/10.16997/jdd.377

Submitted: 15 February 2020 Accepted: 21 May 2020 Published: 14 October 2020

Copyright: ( $) 2020$ The Author(s). This is an open-access article distributed under the terms of the Creative Commons Attribution 4.0 International License (CC-BY 4.0), which permits unrestricted use, distribution, and reproduction in any medium, provided the original author and source are credited. See http://creativecommons.org/licenses/by/4.0/.
} 